\title{
PROTOTIPE APLIKASI MANAJEMEN SPAREPART ATM MENGGUNAKAN FRAMEWORK ZACHMAN PADA LOGISTIK ASP
}

\author{
Ridlan Ahmad ${ }^{1)}$, Kusrini $^{2}$ \\ 1), 2) Magister Teknik Informatika, Program Pasca Sarjana, Universitas Amikom Yogyakarta \\ 1),2) Jl. Ringroad Utara, Condong Catur, Sleman, Yogyakarta \\ Telp: (0274) 884201-207 Fax: (0274) 884208 Kodepos: 55283 \\ E-Mail: $\underline{\text { amikom@amikom.ac.id }}$
}

Email : ahmadridlan@yahoo.co.id ${ }^{1)}$, kusrini@amikom.ac.id ${ }^{2)}$

\begin{abstract}
Intisari - Logistik ASP merupakan tempat penitipan sparepart ATM dimana salah satu cabang yang dimiliki oleh perusahan tersebut yaitu Logistik ASP di kota. Manajemen sparepart ATM pada Logistik ASP telah memiliki prosedur data masuk dan data keluar sparepart ATM yang baik, akan tetapi sistem tersebut masih dilakukan secara manual seperti laporan yang diketik pada microsoft excel dan juga ditulis pada laporan kerja Stock Request Form (SRF). Penelitian yang dilakukan bertujuan untuk menganalisis dan merancang suatu prototipe aplikasi Manajemen terhadap Sparepart ATM pada Logistik ASP. Model Analisis dalam pengumpulan data menggunakan analisis SWOT, sementara EA Score card sebagai uji kelayakan apakah system ini layak untuk dipakai. Dan perancangan yang dilakukan menggunakan arsitektur enterprise Zachman Framework dan pendekatan UML Pemetaan terhadap Zachman Framework dalam penelitian ini dibatasi hanya pada perspektif Planner, Owner, dan Designer sedangkan masing-masing kolomnya terdiri atas Data (What), Function (How), Network (Where), People (Who), Time (When) dan Motivation (Why).

Hasil dari analisis dan rancangan yang dilakukan, dihasilkan suatu prototipe Manajemen Sparepart ATM yang dapat mengontrol seluruh aktivitas-aktivitas part secara optimal yang terdiri dari data stok barang, data penggunaan part, data part masuk dan data return (pengembalian) part yang selanjutnya diimplementasikan sebagai gambaran interface sistem yang akan dibangun.

Dengan menggunakan arsitektur enterprise Zachman Framework, diperoleh informasi secara detail tentang bagaimana sistem informasi manajemen sparepart ATM itu dirancang, serta segala kebutuhan baik data, sumber daya manusia dan infrastruktur yang mendukung berjalannya sistem informasi tersebut.
\end{abstract}

Kata kunci — Kata kunci: Logistik, Analisis SWOT, EA Score card. Zachman Framework, UML, Manajemen Sparepart ATM

Abstract-ASP Logistics is a place for depositing ATM spare parts where one of the branches owned by the company is ASP Logistics in city. ATM spare parts management in ASP Logistics has good procedures for incoming data and outgoing spare parts for ATMs, but the system is still done manually such as reports typed in Microsoft Excel and also written on the Stock Request Form (SRF) work report. The research aimed to analyze and design a model of Management Information Systems for ATM Spare Parts at ASP Logistics. The analysis model in collecting data uses a SWOT analysis, while the EA Score card is a test of whether this system is feasible to use. And the design carried out using the Zachman Framework enterprise architecture and the UML approach Mapping of the Zachman Framework in this study is limited only to the perspective of the Planner, Owner and Designer while each column consists of Data (What), Function (How), Network (Where), People (Who), Time (When) and Motivation (Why).

The results of the analysis and design carried out, produced an ATM Spare Parts Management Information System model that can control all part activities optimally consisting of inventory data, part usage data, part entry data and data return (return) parts which are subsequently implemented in the form of a prototype as an illustration of the system interface to be built.

By using the Zachman Framework enterprise architecture, detailed information is obtained about how the ATM spare parts management information system is designed, as well as all the needs of data, human resources and infrastructure that support the operation of the information system.

Keywords—Logistics, SWOT Analysis, EA Score card. Zachman Framework, UML, ATM Spare Parts Management

\section{PENDAHULUAN}

Adapun suatu perusahan jasa yang memproduksi, menjual, dan memelihara (maintenance) Anjungan Tunai Mandiri (ATM) yang kemudian dijual pada perbankan Badan Usaha Milik Negara (BUMN) maupun swasta dan selanjutnya didelivery ke kantor-kantor cabang yang ada di Indonesia. Guna me-maintenance ATM, perusahaan jasa tersebut menempatkan karyawannya di seluruh provinsi di Indonesia sebagai field engineering (FE) guna pelayanan ke customer perbankan sebagai garansi bilamana ATM yang dibeli terjadi kerusakan dan jika memerlukan pergantian sparepart. Untuk pengelolaan dan penyimpanan sparepart ATM pada perusahaan jasa penyedia ATM, dikuasakan kepada Logistik ASP. ASP merupakan perusahan ekspedisi penyedia jasa pengiriman barang sedangkan Logistik ASP disebut sebagai tempat penitipan sparepart ATM di mana salah satu cabang yang dimiliki oleh perusahan yaitu Logistik ASP. 
Manajemen sparepart ATM pada Logistik ASP telah memiliki prosedur data masuk dan data keluar sparepart ATM yang baik, tetapi sistem tersebut masih bersifat konvensional serta belum memiliki aplikasi yang dapat mem-backup seluruh data part masuk, data part keluar, dan part backup pada database. Oleh karena sifat kerja dari manajemen sparepart yang masih diinput secara manual tersebut, maka memungkinkan terjadinya selisih dan kehilangan sparepart sangat besar. Selain itu, juga diketahui bahwa sering terjadi kekosongan part serta adanya data part yang terpakai tetapi masih dianggap belum terpakai sebagai data part backup yang juga menyebabkan terjadinya selisih.

Enterprise Architecture (EA) merupakan sebuah pendekatan logis, komprehensif dan holistik untuk merancang dan mengimplementasikan sistem komponen sistem secara bersamaan [1]. Menurut Osvalds dan Gundars, EA merupakan deskripsi dari misi stakeholder yang di dalamnya termasuk informasi, fungsionalitas/ kegunaan, lokasi organisasi dan parameter kinerja serta menggambarkan rencana untuk mengembangkan sebuah sistem atau sekumpulan sistem [1]. Untuk dapat memaksimalkan peran EA, diperlukan sebuah framework yang memiliki model simbolis untuk menspesifikasikan berbagai fase EA.

Ada beragam jenis framework yang dapat menunjukkan perkembangan konsep dari EA, seperti Zachman Framework, Federal Enterprise Architecture Framework (FEAF), DoD Architecture Framework (DoDAF), Treasury Enterprise Architecture Framework (TEAF), serta The Open Group Architecture Framework (TOGAF). Menurut survei yang dilakukan oleh Institute For Enterprise Architecture Development (IFEAD) pada tahun 2005, menerangkan bahwa framework yang banyak digunakan dalam dunia industri dan pemerintahan adalah Zachman Framework, TOGAF dan FEAF dengan persentase tertinggi dimiliki oleh Zachman Framework sebesar 25\% [2]. Adapun hasil survei yang dilakukan oleh IFEAD tersebut, yang selanjutnya dapat divisualisasikan melalui gambar 1 berikut, yaitu:

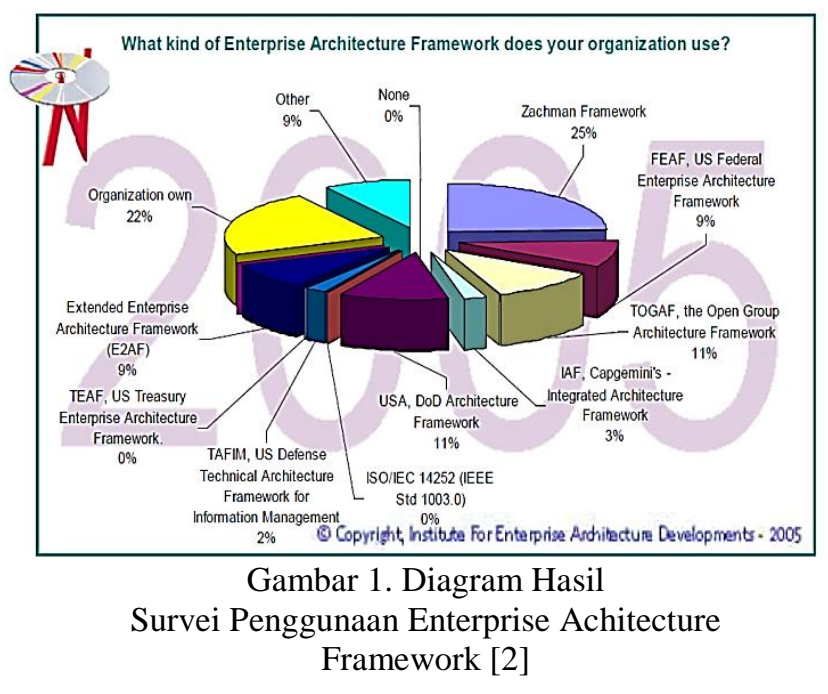

Zachman Framework adalah kerangka kerja arsitektur enterprise yang menyediakan cara untuk memandang dan mendefinisikan sebuah enterprise secara formal dan terstruktur dengan baik [3]. Zachman Framework juga merupakan suatu pendekatan secara luas yang dapat digunakan untuk mengembangkan atau mendokumentasikan arsitektur perusahaan-perusahaan [4]. Dengan kata lain, Zachman Framework merupakan sebuah framework yang digunakan untuk memodelkan EA secara detail dan menyeluruh hal-hal penting yang menjadi dasar dari sebuah perusahaan. Framework ini terdiri atas matrik klasifikasi dua dimensi yang dibangun dari kombinasi beberapa pertanyaan umum yaitu What, Where, When, Why, Who dan How.

Dalam penelitian ini, akan dilakukan perancangan prototipe Aplikasi Manajemen Sparepart ATM pada Logistik ASP guna mengontrol seluruh aktivitas part ATM, di mana sistem ini tidak akan mengubah arus dokumen atau prosedurprosedur lainnya. Akan tetapi, beberapa sistem yang digunakan akan mengalami sedikit penyesuaian sesuai kebutuhan sebagai input dalam proses penyajian data, beserta dengan bentuk laporan-laporan yang akan disajikan. Selanjutnya, analisis yang dilakukan bertujuan untuk memperoleh informasi-informasi terhadap permasalahan penelitian dan mendefinisikan kebutuhan dengan tujuan untuk menganalisis kebutuhan sistem dan mengetahui kelemahan dari sistem lama atau yang sedang berjalan. Sementara itu, dalam merancang EA Model prototipe Aplikasi Manajemen Sparepart ATM pada Logistik ASP akan digunakan pendekatan EA Zachman Framework yang mana masingmasing kolomnya terdiri atas Data (What), Function (How), Network (Where), People (Who), Time (When) dan Motivation (Why). Adapun dari sisi perspektif hanya akan menjabarkan dari sudut pandang Planner, Owner, dan Designer. Selanjutnya, dalam penelitian ini juga akan dilakukan pengujian maupun pengukuran terhadap kelayakan perancangan prototipe Aplikasi Manajemen Sparepart ATM yang telah dirancang. Adapun pengujian yang dilakukan menggunakan metode EA Score Card guna mengetahui kelayakan dari model sistem tersebut. Hasil dari perancangan arsitektur dan pengujian kelayakan yang dilakukan, selanjutnya akan diimplementasikan dalam bentuk gambaran interface aplikasi yang dibangun, di mana prototype ini hanya meliputi data stok barang, data penggunaan part, data return part, serta part masuk.

\section{Metodologi Penelitian}

\subsection{Jenis dan Pendekatan Penelitian}

\subsubsection{Jenis Peneilitian}

Jenis penelitian yang dilakukan merupakan jenis penelitian tindakan (action research), di mana peneliti melakukan tindakan terhadap permasalahan maupun fenomena yang terjadi terkait dengan obyek yang diamati guna menyelesaikan permasalahan yang dihadapi oleh suatu organisasi/ perusahaan. Menurut Mc Taggart, penelitian tindakan (action research) adalah cara suatu kelompok atau seseorang dalam mengorganisasi suatu kondisi sehingga mereka dapat mempelajari pengalaman mereka dan membuat pengalaman tersebut dapat diakses oleh orang lain [11].

\subsubsection{Pendekatan Penelitian}

Adapun pendekatan penelitian yang digunakan dalam merancang prototipe Aplikasi Manajemen Sparepart ATM pada Logistik ASP , yaitu dengan menggunakan pendekatan EA Zachman Framework. Adapun area kerja dari Zachman Framework yang dilibatkan dalam melakukan perancangan, 
yaitu ditinjau berdasarkan perspektif Planner (Scope Context), perspektif Owner (Business Concept), dan perspektif Designer (System Logic). Selanjutnya, masing-masing dari perspektif tersebut kemudian dijelaskan secara rinci berdasarkan enam kolom yang masing-masing kolomnya terdiri dari What (Data), How (Proses), Where (Lokasi), Who (Orang), When (Waktu), dan Why (Motivasi). Berikut adalah penjabaran dari matrik Zachman terhadap penelitian yang dilakukan, yaitu antara lain:

a. Kolom What. Menjelaskan tentang data yang dapat disajikan dari perspektif Planner, Owner, dan Designer.

b. Kolom How. Kolom ini membahas tentang proses-proses yang terjadi pada Logistik ASP .

c. Kolom Where. Kolom ini membahas tentang lokasi bisnis utama tempat sistem informasi berada beserta infrastruktur dan konfigurasinya.

d. Kolom Who. Kolom ini membahas tentang sumber daya manusia yang berperan penting dalam proses pelaporan dan penanganan terhadap sparepart ATM pada Logistik ASP.

e. Kolom When. Kolom ini membahas tentang kejadian atau kegiatan beserta jadwalnya. Kegiatan utama yang akan dibahas adalah yang berkaitan dengan pelaporan data sparepart ATM.

f. Kolom Why. Menjabarkan tentang misi, visi, tujuan, motivasi dan inisiatif serta batasan-batasan yang ditetapkan berkaitan dengan sistem informasi yang akan dibangun.

\subsection{Metode Pengumpulan Data}

Untuk menjawab permasalahan yang telah dirumuskan, maka diperlukan adanya data awal guna mengetahui masalah yang ditimbulkan oleh sistem yang ada, mendeskripsikan pandangan user terhadap sistem tersebut, serta mengetahui apa yang dibutuhkan user terhadap sistem yang akan dibangun/ dirancang dan hal-hal apa saja yang mampu dilakukan oleh sistem yang baru hingga akhirnya dapat memilih sistem yang tepat. Data tersebut dapat diperoleh dengan menggunakan beberapa metode atau teknik yang digunakan dalam mengumpulkan data, yaitu dengan menggunakan metode wawancara, observasi, dan studi pustaka.

\subsection{Metode Analisis Data}

Adapun metode analisis yang digunakan untuk menganalisis uji kelayakan perancangan arsitektur dalam penelitian ini yang selanjutnya berdasarkan data yang terkumpul tersebut kemudian diolah dan dianalisis secara kualitatif dan kuantitatif, yaitu dengan menggunakan metode EA Score Card. Selanjutnya, metode analisis tersebut dapat dijelaskan sebagai berikut:

\subsubsection{Metode EA Score Card}

Uji kelayakan terhadap arsitektur yang dirancang, bertujuan untuk mengetahui apakah arsitektur yang dibuat nantinya layak untuk dapat diimplementasikan menjadi sebuah SIM Sparepart ATM. Adapun metode yang digunakan untuk menguji kelayakan EA tersebut yaitu dengan menggunakan metode EA Score Card. Penggunaan metode EA Score Card bertujuan untuk mengukur atau menguji kelayakan kualitas kesiapan implementasi sebuah arsitektur.
Selanjutnya, untuk mengukur kelayakan terhadap EA perancangan prototipe Aplikasi Manajemen Sparepart ATM tersebut diperlukan alat untuk mengukurnya. Alat tersebut ialah EA Score Card yang diperkenalkan oleh Jaap Schekkerman [11]. EA Score Card merupakan alat pengukur kelayakan persiapan penerapan perencanaan enterprise arsitektur [12]. Penggunaan EA Score Card dalam melakukan uji kelayakan rancangan terhadap EA model perancangan prototipe Aplikasi Manajemen Sparepart ATM, berfokus pada proses aktivitas suatu organisasi atau perusahaan, data, aplikasi dan teknologi yang berkaitan. EA Score Card merupakan alat ukur berupa pertanyaan-pertanyaan berupa assesment untuk mengukur kualitas kesiapan implementasi sebuah arsitektur [11]. Pertanyaan-pertanyaan assesment tersebut disajikan dalam bentuk tabel EA Score Card yang dikembangkan oleh Schekkerman [12]. Tabel EA Score Card memiliki tiga definisi status, yaitu [12]:

a. " $0 "=$ Unclear, tidak teridentifikasi, tidak terdefinisikan, tidak didokumentasikan.

b. " $1 "=$ Partially Clear, sudah diidentifikasi, sudah didefinisikan, ada dokumentasi.

c. " $2 "=$ Clear, diidentifikasi dan didefinisikan dengan jelas dengan dokumentasi yang sesuai.

Setelah tabel EA Score Card telah diisi, maka dilanjutkan dengan melakukan perhitungan terhadap hasil pengujian. Hasil dari pengujian dengan menggunakan EA Score Card kemudian dikualifikasikan berdasarkan kriteria kelayakan kualitas kesiapan implementasi sebuah arsitektur. Adapun kriteria kelayakan tersebut, yaitu sebagai berikut [12]:

a. Jika hasil pengujian kematangan arsitektur secara keseluruhan yang dicapai < 50\% maka arsitektur dinyatakan "Tidak Layak".

b. Jika hasil pengujian kematangan arsitektur secara keseluruhan yang dicapai > 50\% maka arsitektur dinyatakan "Layak".

\subsection{Alur Penelitian}

Melakukan analisis dan perancangan untuk menghasilkan suatu arsitektur Perancangan Prototipe Aplikasi Manajemen Sparepart ATM pada Logistik ASP, memiliki beberapa tahapan dalam penelitian ini. Adapun langkah-langkah dalam penelitian ini, yang dapat divisualisasikan melalui gambar 3 berikut, yaitu: 


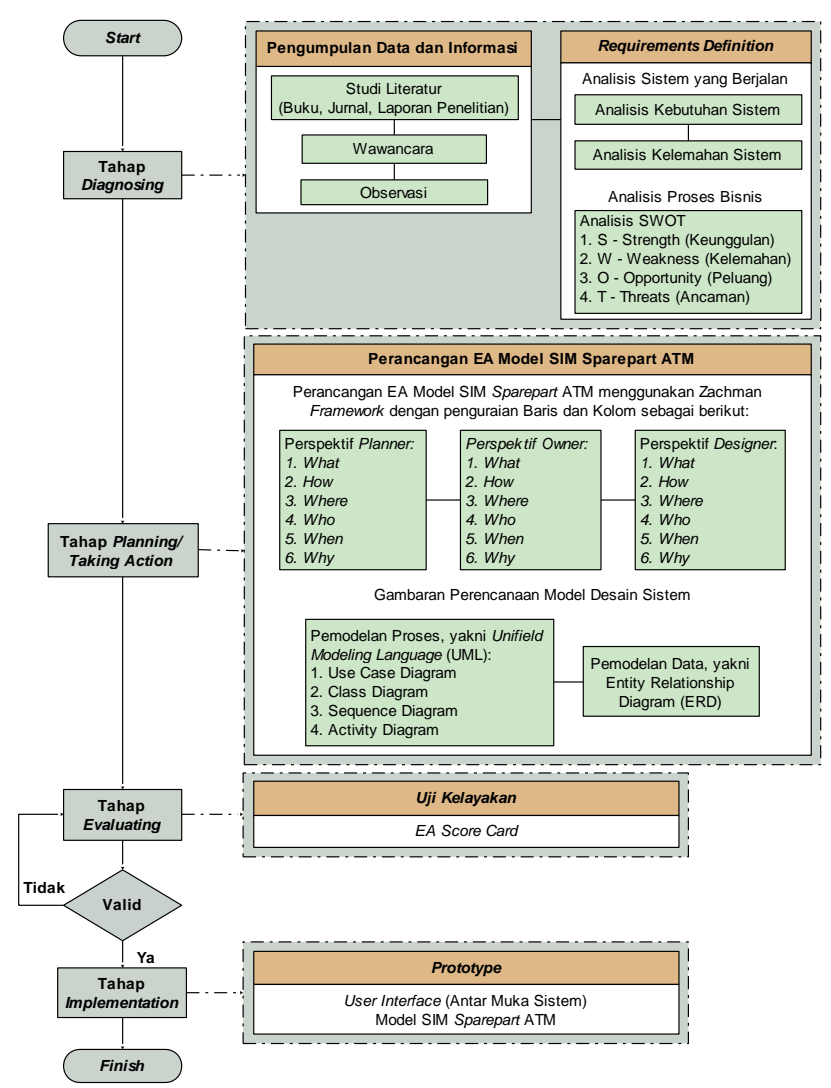

Gambar 3. Alur Penelitian

\section{HASIL DAN PEMBAHASAN}

\subsection{Analisis dan Rancangan Sistem}

Analisis yang dilakukan bertujuan untuk memperoleh informasi-informasi terhadap permasalahan penelitian dan mendefinisikan kebutuhan dengan tujuan untuk menganalisis kebutuhan sistem dan mengetahui kelemahan dari sistem lama atau yang sedang berjalan. Adapun hasil analisis yang diperoleh, yaitu sebagai berikut:

\subsubsection{Analisis Kebutuhan dan Kelemahan Sistem}

Berdasarkan hasil wawancara dan observasi yang telah dilakukan, ditemukan beberapa permasalahan yang dihadapi oleh Logistik ASP, yaitu bahwa sistem kerja yang dimiliki masih bersifat konvensional atau manual serta belum memiliki aplikasi yang dapat mem-backup seluruh data part masuk, data part keluar, dan part backup pada database perusahaan. Sehingga memungkinkan terjadinya selisih dan kehilangan sparepart sangat besar. Selain itu, juga diketahui bahwa sering terjadi kekosongan part serta adanya data part yang terpakai tetapi masih dianggap belum terpakai sebagai data part backup yang juga menyebabkan terjadinya selisih. Berdasarkan hal tersebut, maka dapat diketahui bahwa sistem lama atau yang berjalan saat ini masih kurang optimal karena dilakukan secara konvensional atau manual dengan menggunakan buku (manual book), yang dimulai dari proses pencatatan data barang, stok barang, data pengembalian barang, laporan barang, dan lain-lain.

Adapun kelemahan pada sistem lama atau sistem yang sedang berjalan saat ini, yaitu sebagai berikut:

a. Sistem yang sedang berjalan saat ini belum terkomputerisasi dengan baik. b. Adanya kemungkinan data hilang sangat besar karena buku/ kertas mudah hilang atau tercecer.

Dalam pembuatan laporan pun terhambat/ kurang efisien karena harus diolah manual datanya.

3.1.2. Rancangan Model Sistem

Perancangan arsitektur model sistem yang dilakukan, disusun berdasarkan proses pemetaan pada kerangka kerja (framework) Zachman guna menghasilkan rancangan sistem yang dibutuhkan. Setelah peta masalah didapatkan maka selanjutnya masalah-masalah tersebut akan disusun dalam kerangka matrik Zachman. Setelah matrik Zachman diperoleh maka masing-masing baris dan kolom pada matrik tersebut akan diuraikan satu per satu.

Adapun area kerja dari kerangka kerja Zachman yang dilibatkan dalam melakukan perancangan, yaitu ditinjau berdasarkan perspektif Planner (Scope Context), perspektif Owner (Business Concept), dan perspektif Designer (System Logic). Selanjutnya, masing-masing dari perspektif tersebut kemudian dijelaskan secara rinci berdasarkan enam kolom yang masing-masing kolomnya terdiri dari What (Data), How (Proses), Where (Lokasi), Who (Orang), When (Waktu), dan Why (Motivasi).

Secara rinci, matrik Zachman terhadap Perancangan Model SIM Sparepart ATM pada Logistik ASP dapat dilihat pada tabel 1 berikut, yaitu:

Tabel 1. Zachman Framework terhadap Prototipe Aplikasi Manajemen Sparepart ATM pada Logistik ASP

\begin{tabular}{|c|c|c|c|c|c|c|}
\hline & $\begin{array}{l}\text { DATA } \\
\text { What }\end{array}$ & $\begin{array}{c}\text { FUNCTION } \\
\text { How }\end{array}$ & $\begin{array}{c}\text { NETWORK } \\
\text { Where }\end{array}$ & $\begin{array}{c}\text { PEOPLE } \\
\text { Who }\end{array}$ & $\begin{array}{l}\text { TIME } \\
\text { When }\end{array}$ & $\begin{array}{c}\text { MOTIVATION } \\
\text { Why }\end{array}$ \\
\hline $\begin{array}{l}\text { Scope } \\
\text { (Planner) }\end{array}$ & \begin{tabular}{|l|} 
Data stok \\
barang \\
penggunaan \\
part, part \\
masuk, \\
return part \\
\end{tabular} & \begin{tabular}{|l|} 
Proses \\
pelaporan \\
sparepart \\
ATM \\
ATM
\end{tabular} & \begin{tabular}{|l|} 
Jalan \\
Cendana I, \\
BTN Kebun \\
Cengkeh \\
Ambon
\end{tabular} & $\begin{array}{l}\mathrm{Kep}, \mathrm{Cab}, \mathrm{PJ}, \\
\mathrm{FE}, \\
\text { Customer } \\
\text { BANK }\end{array}$ & $\begin{array}{l}\text { Lihat stok } \\
\text { barrang, } \\
\text { Update data } \\
\text { penggunaan } \\
\text { partdan part } \\
\text { masuk, input } \\
\text { sparepart } \\
\text { rusalk }\end{array}$ & $\begin{array}{l}\text { Visi dan Misi } \\
\text { Logistik ASP } \\
\text { Ambon }\end{array}$ \\
\hline $\begin{array}{l}\text { Business } \\
\text { Model } \\
\text { (Owner) }\end{array}$ & $\begin{array}{l}\text { Use Case } \\
\text { Diagram }\end{array}$ & $\begin{array}{l}\text { Activity } \\
\text { Diagram } \\
\text { Admin dan } \\
\text { SuperAdmin }\end{array}$ & \begin{tabular}{|l|} 
Desain \\
Jaringan \\
Sistem yang \\
ada atau \\
sedang \\
berjalan \\
\end{tabular} & $\begin{array}{l}\text { Programer, } \\
\text { Desainer, } \\
\text { Administrator, } \\
\text { Operator }\end{array}$ & $\begin{array}{l}\text { Time Schedule } \\
\text { Pembangunan } \\
\text { proyek } \\
\text { SIM }\end{array}$ & $\begin{array}{l}\text { Tujuan atau } \\
\text { alasan } \\
\text { pengadaan } \\
\text { SIM Sparepart }\end{array}$ \\
\hline $\begin{array}{l}\text { System } \\
\text { Modtel } \\
\text { (Designer) }\end{array}$ & ER Diagram & $\begin{array}{l}\text { Sequence } \\
\text { Diagram }\end{array}$ & $\begin{array}{l}\text { Desain } \\
\text { Jaringan } \\
\text { Usulan }\end{array}$ & $\begin{array}{l}\text { Rancangan } \\
\text { Manual } \\
\text { Interface SIM }\end{array}$ & $\begin{array}{l}\text { Detail jadwal } \\
\text { perancangan } \\
\text { model } \\
\text { SIM }\end{array}$ & $\begin{array}{l}\text { Aturan-aturan } \\
\text { atau batasan } \\
\text { dalam } \\
\text { pembuatan } \\
\text { model SIM } \\
\text { Sparepart } \\
\end{array}$ \\
\hline
\end{tabular}

Berdasarkan tabel 1, masing-masing kolom akan diuraikan berdasarkan abstraksi yang dilihat dari sudut pandang atau perspektif Planner, Owner, dan Designer. Adapun penjelasan terhadap sudut pandang tersebut, yaitu sebagai berikut:

a. Perspektif Planner

Perspektif planner bertujuan untuk mengidentifikasikan ruang lingkup secara umum mengenai hal-hal penting terkait dengan pengembangan sistem pada Logistik ASP.

1) What (Data)

Kolom ini menerangkan tentang data-data atau entitas yang berkaitan dengan sistem informasi manajemen sparepart ATM pada Logistik ASP . Dari hasil analisis, data-data tersebut dikelompokkan menjadi empat bagian, yaitu:

a) Data Stok Barang.

b) Data Part Masuk.

c) Data Penggunaan Part.

d) Data Return Part atau pengembalian part.

2) How (Proses)

Kolom ini membahas tentang proses-proses yang terjadi pada Logistik ASP Adapun proses utama yang terjadi yaitu 
mengenai proses pelaporan terhadap sparepart ATM. Prosesproses tersebut diantaranya yaitu proses pelaporan data stok barang, proses pelaporan data part masuk, proses pelaporan data penggunaan part, dan proses pelaporan data return atau pengembalian part.

3) Where (Lokasi)

Kolom ini membahas tentang lokasi bisnis utama yaitu lokasi di mana Logistik ASP berada. Adapun lokasi dari Logistik ASP yaitu berlokasi di Jalan Cendana 1, BTN Kebun Cengkeh.

4) Who (Pelaku/ SDM)

Kolom ini membahas tentang sumber daya manusia yang berperan penting dalam proses pelaporan terhadap sparepart ATM pada Logistik ASP . Berikut ini adalah orang-orang yang berperan penting dalam proses tersebut, yaitu:
a) Kepala Cabang Logistik ASP Ambon
b) Penanggung Jawab Logistik ASP Ambon
c) Field Engineering (FE)
d) Customer BANK

5) When (Waktu)

Pada kolom When ini, dijelaskan mengenai pendefinisian kegiatan-kegiatan dan alokasi penggunaan waktu yang terjadi di Logistik ASP pada saat transaksi. Untuk kegiatan utama yang akan dibahas adalah yang berkaitan dengan pelaporan sparepart ATM. Adapun kegiatan-kegiatan tersebut, antara lain yaitu:

a) Data stok barang. Pelaporan terhadap data stok barang dilakukan setiap seminggu sekali dan ditentukan berdasarkan kondisi gudang, permintaan pasar, barang masuk, barang yang rusak, perencanaan pembelian dan pengiriman barang.

b) Data penggunaan part. Penggunaan part terjadi ketika adanya permintaan baru pihak BANK ketika ATM pada BANK tersebut terjadi problem dengan mengirimkan email ke kantor perusahaan ATM, sehingga dari perusahaan ATM mengelurkan tiket problem dan diteruskan ke CSE atau user. Selanjutnya dengan tiket tersebut, CSE ke Logistik ASP untuk menganbil part dan memasang di ATM BANK tersebut. Dengan demikian, aplikasi manajemen sparepart ATM ASP akan mengupdate data part yang diambil oleh CSE dan menyimpan sebagai data penggunaan part.

c) Data part masuk. Data part masuk adalah data part yang dikirim dari pusat tiap minggu dan di-update pada sistem aplikasi manajemen sparepart ATM ASP .

d) Data return part. Adalah pengembalian part mingguan yang dilakukan ASP . Part tersebut diperoleh dari sparepart bad yang dibawa kembali oleh CSE, yang sebelumnya dipasang pada BANK yang ATM-nya rusak dan perlu pergantian sparepart. Return part telah terkirim ketika nomor resi pengiriman (AWB) telah ada.

6) Why (Motivasi)

Kolom Why, membahas mengenai hal-hal yang ingin dicapai oleh Logistik ASP . Oleh sebab itu, adapun visi dan misi dari perusahaan Logistik ASP , yaitu sebagai berikut:

a) Visi:

Menjadi perusahaan jasa ekspedisi yang mampu memberikan nilai pelayanan yang terbaik untuk pelanggan di Indonesia b) Misi:

(1) Memberikan jasa ekspedisi dengan layanan dan harga yang optimal dan berkualitas.

(2) Menjadi pilihan terbaik di kelasnya dan memperluas akses jasa eskpedisi bagi semua pelanggan.

Mendorong pertumbuhan usaha yang berkesinambungan untuk meningkatkan nilai perusahaan, kesejahteraan karyawan dan peduli pada tanggunjawab sosial.

b. Perspektif Owner

Perspektif dari baris kedua pada Zachman Framework ini akan dijabarkan kolom-kolom Zachman dari sudut pandang pemilik atau orang yang paling bertanggung jawab terhadap pengelolaan sparepart pada Logistik ASP . Berdasarkan perspektif ini, owner akan menyampaikan usulan sebuah sistem dan bagaimana sistem tersebut dapat digunakan dalam gambaran yang masih sederhana, yaitu untuk memanajemen data sparepart ATM pada Logistik ASP.

1) What (Data)

Bagian ini menjelaskan bagaimana proses yang sudah ditentukan pada perspektif Planner berhubungan dalam menjalankan proses pelaporan pada Prototipe Aplikasi Manajemen Sparepart ATM pada Logistik ASP . Adapun proses yang terjadi yang dapat disajikan melalui gambar 4 berikut:

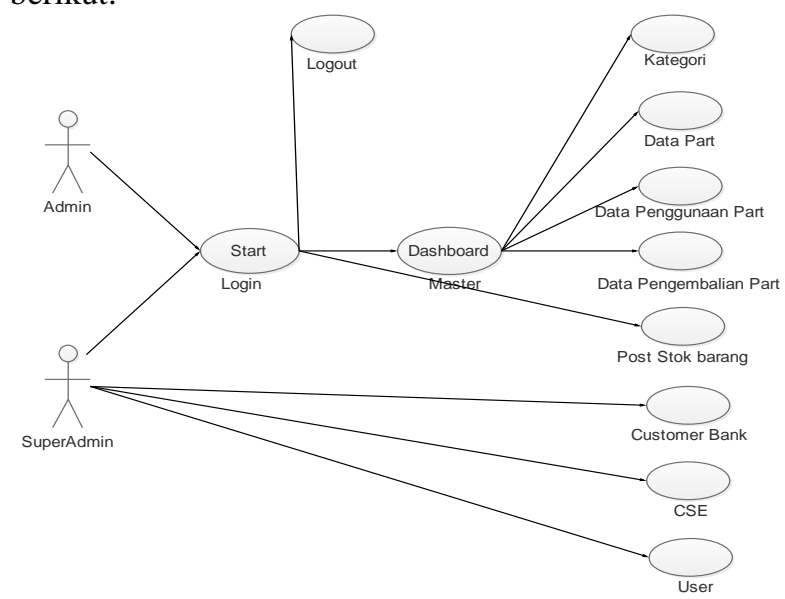

Gambar 4. Use Case Pelaporan pada Prototipe Aplikasi Manajemen Sparepart ATM pada Logistik ASP

2) How (Proses)

Kolom ini menjabarkan tentang proses yang terjadi pada diagram yang dibuat pada kolom what. Adapun proses-proses tersebut yaitu sebagai berikut:

a) SuperAdmin dapat mengakses semua menu pada dashboard, diantaranya yaitu Menu Master (kategori barang, data part, data penggunaan part, data pengembalian part), Menu Stok Barang, Menu Customer BANK, Menu CSE dan Menu User.

b) Admin hanya dapat mengakses Menu Master (kategori barang, data part, data penggunaan part, data pengembalian part) dan Menu Stok Barang.

Adapun proses pada SuperAdmin dan Admin yang dapat disajikan melalui gambar 5 dan gambar 6 berikut: 


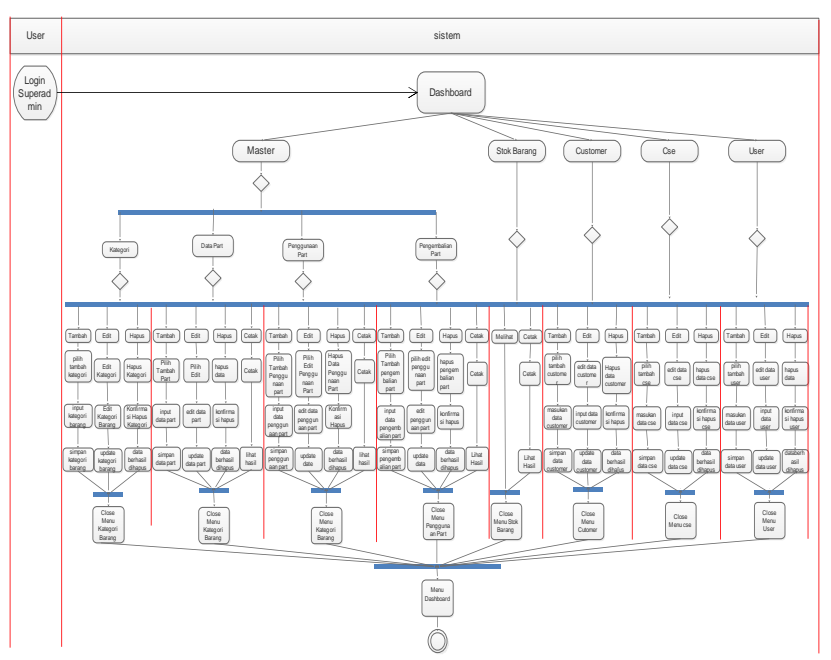

Gambar 5. Activity Diagram SuperAdmin

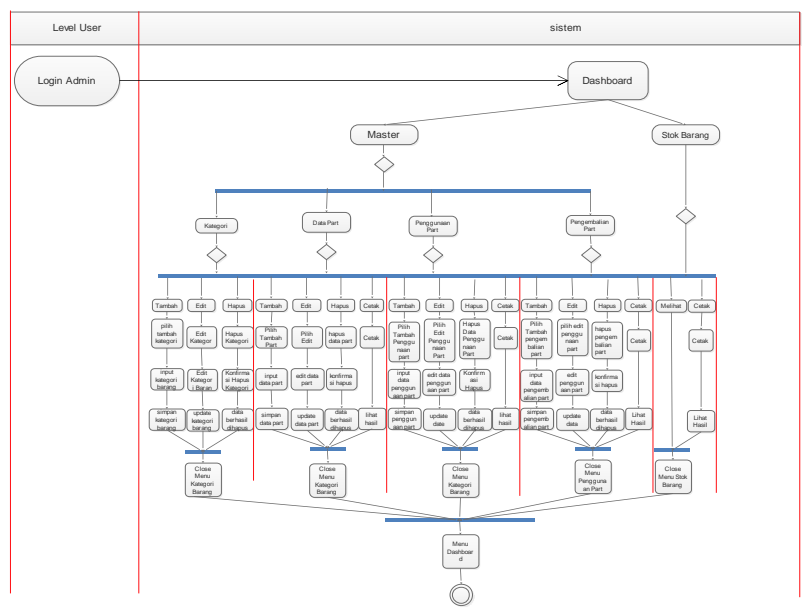

Gambar 6. Activity Diagram Admin

Berdasarkan proses yang dapat dilakukan pada setiap entitas dari Admin dan SuperAdmin, terdapat batasan yang tidak dapat dilakukan pada Admin dalam menggunakan sistem informasi tersebut.

3) Where (Lokasi)

Bagian ini mendefinisikan model enterprise dengan memaparkan model jaringan enterprise berupa desain jaringan yang telah diterapkan pada Logistik ASP . Oleh karena sistem manajemen sparepart ATM ini merupakan aplikasi startup, maka diperlukan penggunaan jaringan internet. Adapun desain jaringan yang yang telah diterapkan pada Logistik ASP yang selanjutnya dapat disajikan melalui gambar 4.6 berikut, yaitu:

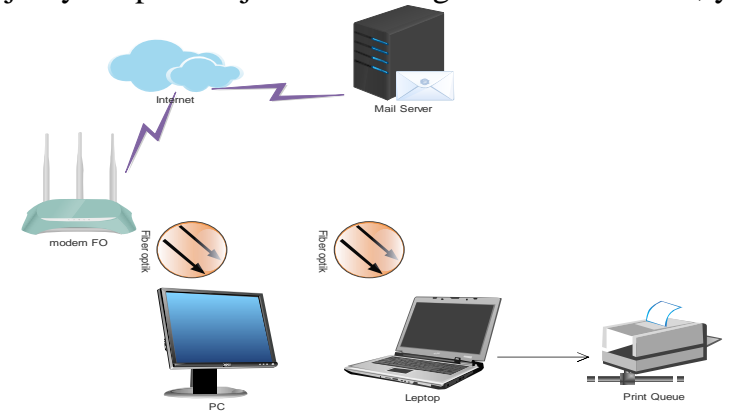

Gambar 7. Peta Jaringan Enterprise Sistem Lama pada Logistik ASP
4) Who (Pelaku/ SDM)

Kolom pada bagian ini menjelaskan tentang sumber daya manusia yang akan yang ditugaskan oleh owner untuk terlibat dalam penggunaan sistem baik dalam proses pembangunan maupun dalam proses pengelolaan terhadap Prototipe Manajemen sparepart ATM pada Logistik ASP . Adapun sumber daya tersebut, yaitu:
a) Desainer Web dan Grafis
b) Teknisi Hardware dan Infrastruktur Jaringan
c) Administrator Jaringan
d) Programer Web
e) Administrator Database
f) Penganggung Jawab Sistem Informasi
g) Pengelola Sparepart
5) When (Waktu)

Pada bagian ini dijelaskan tentang jadwal atau time schedule untuk merancang Prototipe Aplikasi Manajemen Sparepart ATM pada Logistik ASP yang akan ditentukan oleh pihak owner kemudian akan didelegasikan ke tim yang akan melaksanakan proyek. Adapun time schedule terhadap rencana perancangan Prototipe Aplikasi Manajemen Sparepart ATM yang dapat disajikan melalui tabel 2 berikut:

Tabel 2. Time Schedule Rencana Proyek

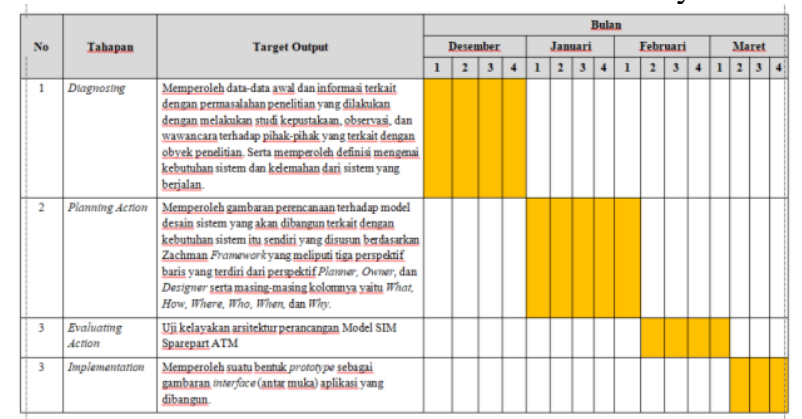

6) Why (Motivasi)

Kolom ini mendefinisikan model enterprise dengan memaparkan alasan maupun tujuan yang diharapkan ataupun yang ingin dicapai oleh Kepala Cabang Logistik ASP terkait dengan perancangan Prototipe Manajemen Sparepart ATM pada Logistik ASP . Adapun alasan-alasan tersebut, yaitu:

a) Ingin merubah pola manajemen sparepart ATM, yang lama ke pola manajemen yang baru. Pada pola yang lama semua data sparepart ATM di data secara manual dan dipertanggungjawabkan atau pelaporannya dilakukan setiap minggu kemudian dikirim dalam bentuk file excel melalui via email ke pusat. Dengan adanya sistem yang baru, diharapkan selisih sparepart lebih diminimalkan dan pertanggungjawaban ke pusat lebih maksimal dengan adanya perancangan SIM sparepart, sehingga peredaran sparepart lebih terkontrol.

b) Ingin membuat manajemen stok barang yang lebih baik pada Logistik ASP .

c) Memaksimalkan kinerja dan mengurangi selisih part, dan pengiriman sparepart dari pusat dapat terkontrol.

d) Mengefektifkan waktu pembuatan laporan data stok barang pada Logistik ASP .

c. Perspektif Designer

Perspektif designer berkaitan dengan aktivitas perantara antara apa yang diinginkan pemilik dan apa yang dapat 
dicapai secara teknis dan fisik. Pada perspektif ini digambarkan model teknis perancangan yang menjadi dasar pedoman implementasi sistem informasi enterprise yang akan dibangun.

\section{1) What (Data)}

Kolom ini mendefinisikan model sistem bagi data dengan mengidentifikasi model data logis. Artifak yang digunakan untuk arsitektur SIM sparepart ATM dapat dilihat dalam perancangan ERD (Entity Relationship Diagram) data yang ada di database dari sistem informasi yang dibangun yang kemudian direlasikan agar ada keterkaitan antara tiap tabel. Selanjutnya, data yang dibangun Prototipe Aplikasi Manajemen Sparepart ATM pada Logistik ASP dapat divisualisasikan melalui gambar 8 berikut:

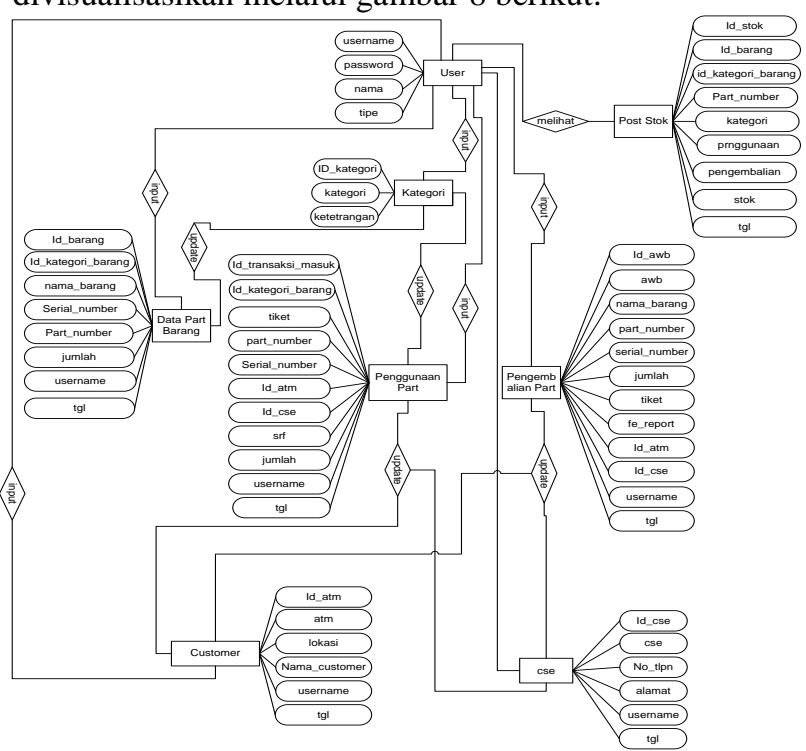

Gambar 8. Entity Relationship Diagram Prototipe Manajemen Sparepart ATM pada Logistik ASP

\section{2) How (Proses)}

Kolom ini mendefinisikan model sistem fungsi dengan mengidentifikasi rancangan Prototipe Aplikasi Manajemen Sparepart ATM pada Logsitik ASP secara lebih detail. Adapun artifak yang digunakan sebagai alur dari sistem yang dibangun yaitu Sequence Diagram yang selanjutnya dapat disajikan melalui gambar 4.8 berikut:

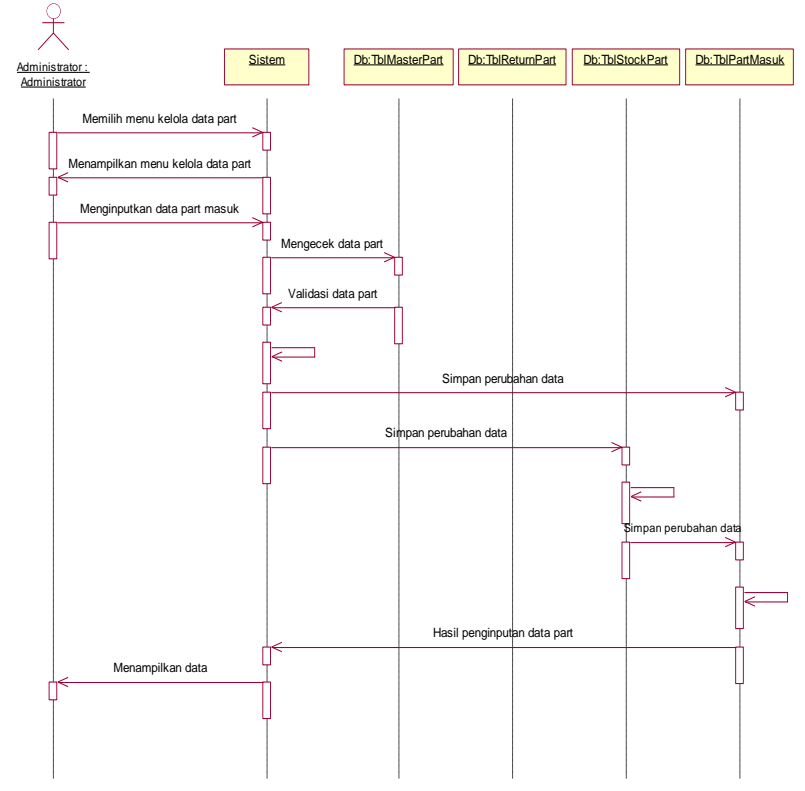

Gambar 9. Sequence Diagram Pengelolaan Part

3) Where (Lokasi)

Kolom ini mendefinisikan arsitektur jaringan logis yang terdiri dari desain topologi jaringan usulan yang akan diterapkan pada Logistik ASP . Adapun desain topologi jaringan yang diusulkan yang selanjutnya dapat disajikan melalui gambar 10 berikut:

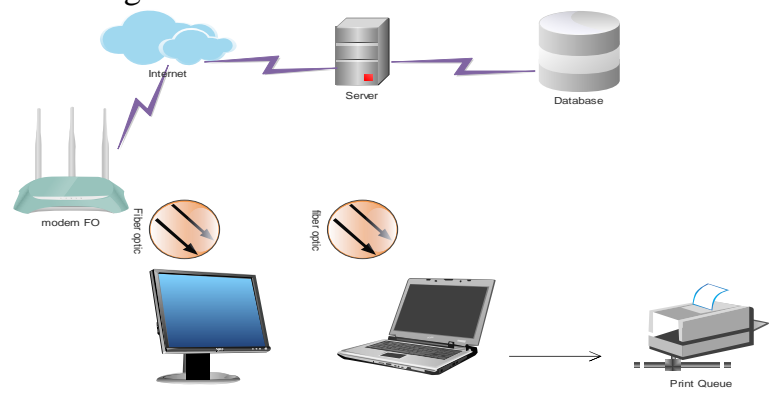

Gambar 10. Peta Jaringan Enterprise Sistem yang Diusulkan pada Logistik ASP

4) Who (Pelaku/SDM)

Kolom ini mendefinisikan arsitektur enterprise yang menggambarkan rancangan manual interface aplikasi Prototipe Aplikasi Manajemen Sparepart ATM di Logistik ASP yang akan dibangun. Adapun rancangan manual interface aplikasi tersebut yang dapat disajikan melalui gambar 11 berikut, yaitu:

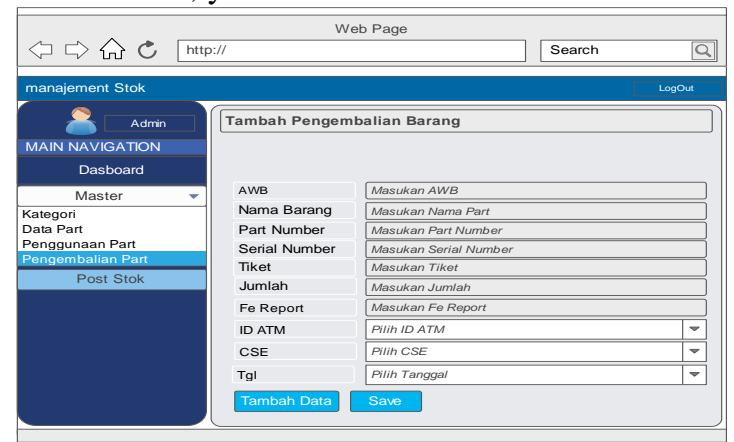

Gambar 11. Desain Interface Return Part 
5) When (Waktu)

Pada kolom ini, dibahas mengenai detail jadwal perancangan Prototipe Aplikasi Manajemen Sparepart ATM pada Logistik ASP . Adapun detail jadwal perancangan Prototipe Manajemen yang nantinya akan dibangun menjadi sebuah aplikasi di Logistik ASP dengan menggunakan GANTT Chart yang selanjutnya dapat disajikan melalui tabel 4.3 berikut, yaitu:

Tabel 3. Detail Jadwal Perancangan Prototipe Aplikasi Manajemen Sparepart ATM

\begin{tabular}{|c|c|c|c|c|c|c|c|c|}
\hline \multirow{3}{*}{ No } & \multirow{3}{*}{ Event } & \multicolumn{7}{|c|}{ Bulan } \\
\hline & & \multicolumn{4}{|c|}{ Januari } & \multicolumn{3}{|c|}{ Februari } \\
\hline & & l & 2 & 3 & 4 & 1 & 2 & 3 \\
\hline 1. & Penentuan Entitas & & & & & & & \\
\hline 2. & Perancangan Use Case Diagram & & & & & & & \\
\hline 3. & Perancangan ERD & & & & & & & \\
\hline 4. & Perancangan Activity Diagram & & & & & & & \\
\hline 5. & Perancangan Sequence Diagram & & & & & & & \\
\hline 6. & Perancangan Database & & & & & & & \\
\hline 7. & Perancangan Antarmuka Sistem & & & & & & & \\
\hline
\end{tabular}

\section{6) Why (Motivasi)}

Kolom pada bagian ini mendefinisikan aturan yang diterapkan dalam proses perancangan Prototipe Aplikasi Manajemen Sparepart ATM pada Logistik ASP . Adapun batasan atau aturan dalam proses perancangan Prototipe Sparepart ATM untuk memudahkan dalam proses kerja ASP Cabang yang sebelumnya pengiriman data hanya dilakukan dengan mengirimkan data excel via email, yaitu sebagai berikut:

a) Penginputan penggunaan part hanya bisa dilakukan jika CSE mengambil part, dengan menunjukan tiket problem yang diajukan oleh customer.

b) Penginputan pengembalian part hanya bisa dilakukan jika CSE mengembalikan Part Bad dari customer dan admin menginputnya di data pengembalian part.

Hak akses Admin yang pada Combo Box Master yang terdiri dari kategori, data part, penggunaan part, dan pengembalian part, dan buttom post stok. Sementara itu, SuperAdmin bisa mengakses semua data pada admin ditambah dengan buttom CSE, Costumer, dan User.

3.2. Evaluating Action (Uji Kelayakan Arsitektur)

Pada tahap ini dilakukan pengujian kelayakan arsitektur yang bertujuan untuk mengetahui apakah arsitektur yang dibuat nantinya dapat diimplementasikan menjadi sebuah Prototipe Aplikasi Manajemen Sparepart ATM untuk Logistik ASP . Pengujian ini menggunakan metode EA Score Card untuk mengukur uji kelayakan kualitas kesiapan implementasi sebuah arsitektur. Setelah tabel EA Score Card telah diisi, selanjutnya dilakukan perhitungan hasil pengujian dengan kriteria hasil pengujian, yaitu sebagai berikut:

a. Jika hasil pengujian kematangan arsitektur secara keseluruhan yang dicapai < 50\% maka arsitektur dinyatakan "Tidak Layak"

b. Jika hasil pengujian kematangan arsitektur secara keseluruhan yang dicapai > 50\% maka arsitektur dinyatakan "Layak"

Adapun hasil pengujian kelayakan EA terhadap Prototipe Aplikasi Manajemen Sparepart ATM yang dapat disajikan melalui tabel hasil assesment EA Score Card pada tabel 5 berikut, yaitu:
Tabel 5. Hasil Assesment EA Score Card

\begin{tabular}{|l|l|l|l|l|l|l|}
\hline \multirow{2}{*}{ No. } & \multirow{2}{*}{ Responden } & \multicolumn{3}{|c|}{ Compliance Architecture Score (\%) } & Architectural \\
\cline { 3 - 6 } & & Bisnis & Data & Aplikasi & Teknologi & Maturity (\%) \\
\hline 1 & Responden A & 64.29 & 71.43 & 65.71 & 55.71 & 64.29 \\
\hline 2 & Responden B & 80.00 & 78.57 & 80.00 & 77.14 & 78.93 \\
\hline 3 & Responden C & 67.14 & 65.71 & 61.43 & 68.57 & 65.71 \\
\hline 4 & Responden D & 67.14 & 64.29 & 64.29 & 64.29 & 65.00 \\
\hline 5 & Responden E & 65.71 & 65.71 & 65.71 & 65.71 & 65.71 \\
\hline 6 & Responden F & 84.29 & 84.29 & 81.43 & 81.43 & 82.86 \\
\hline 7 & Responden G & 91.43 & 80.00 & 80.00 & 77.14 & 82.14 \\
\hline 8 & Responden H & 92.86 & 82.86 & 81.43 & 74.29 & 82.86 \\
\hline 9 & Responden I & 78.57 & 74.29 & 78.57 & 75.71 & 76.79 \\
\hline 10 & Responden J & 95.71 & 98.57 & 97.14 & 98.57 & 97.50 \\
\hline \multicolumn{7}{|l|}{ Overall Architectural Maturity (\%) } \\
\hline
\end{tabular}

Berdasarkan data hasil pengujian kelayakan perancangan EA terhadap Prototipe Manajemen Sparepart ATM dengan menggunakan EA Score Card pada tabel 4, maka dapat disimpulkan bahwa perancangan EA terhadap Prototipe Aplikasi Manajemen Sparepart ATM pada Logistik ASP dinyatakan "Layak" dengan hasil uji kelayakannya sebesar $76,18 \%$ dan dapat menggambarkan situasi setiap area atau elemen-elemen EA yang dibutuhkan.

3.3. Implementasi Sistem

Implementasi dari hasil perancangan menggunakan Zachman Framework selanjutnya diimplementasikan dalam bentuk prototype aplikasi yang dibangun. Dimana prototype ini hanya mengutamakan dari sisi fungsionalitas saja sehingga nantinya masih dapat dikembangkan lebih lanjut. Adapun beberapa proses data yang akan dibahas, yaitu terkait dengan aktivitas pada data stok atau kategori barang, penggunaan part, part masuk dan pengembalian part.

\subsubsection{Data Stok Barang}

Data stok barang menjelaskan tentang semua data part yang ada pada Logistik ASP , dimana terdapat semua jumlah data part yang ada di Logistik ASP, jumlah semua data part yang terpakai, dan semua data pengembalian part yang telah dikembalikan. Adapun hasil perancangan antarmuka untuk aktivitas pada data stok barang yang dapat divisualisasikan melalui gambar 12 berikut, yaitu:

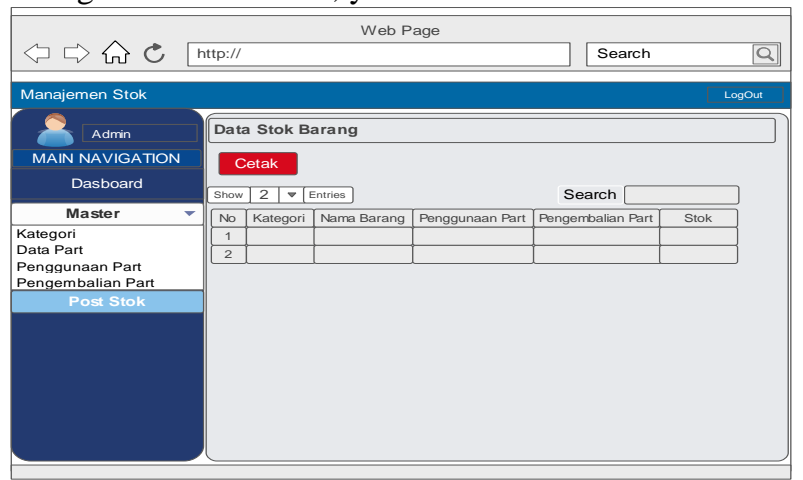

Gambar 12. Tampilan Antarmuka Data Stok Barang

\subsubsection{Data Part Masuk}

Menu data part masuk merupakan tampilan menu yang membahas tentang semua data part yang tersimpan di aplikasi manajemen stok barang. Adapun hasil perancangan antarmuka untuk aktivitas pada data part masuk yang dapat divisualisasikan melalui gambar 13 berikut, yaitu: 


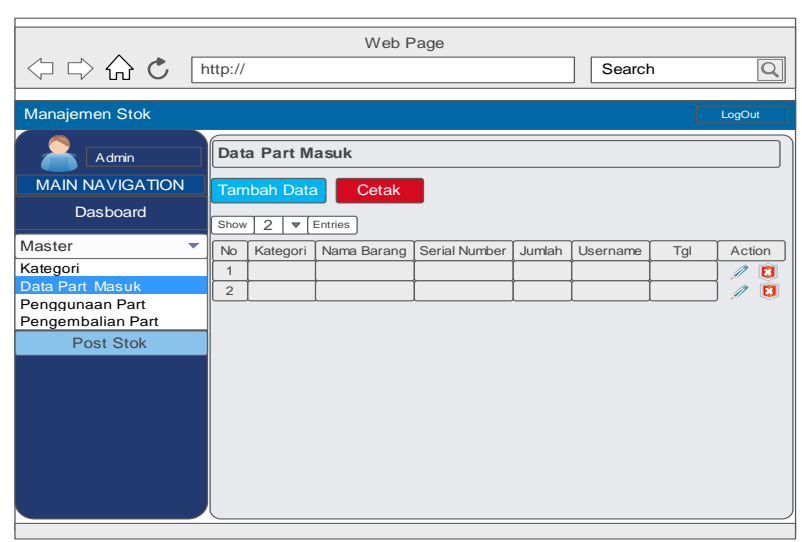

Gambar 13. Tampilan Antarmuka Data Part Masuk

\subsubsection{Data Penggunaan Part}

Menu data penggunaan part merupakan tampilan menu tentang semua data yang digunakan pada ATM yang direquest oleh BANK dengan No. Tiket yang yang di-open ke kantor pusat. Kemudian berdasarkan tiket tersebut, CSE ke ASP untuk mengambil part dan dapat digunakan pada ATM yang rusak, yang selanjutnya sistem akan menginputnya sebagai data penggunaan part. Berikut merupakan hasil perancangan antarmuka untuk aktivitas pada data penggunaan part yang dapat disajikan melalui gambar 14 berikut, yaitu:

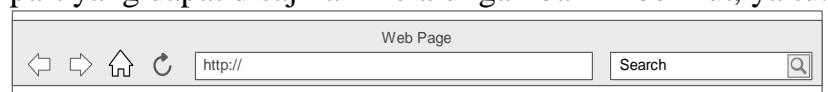

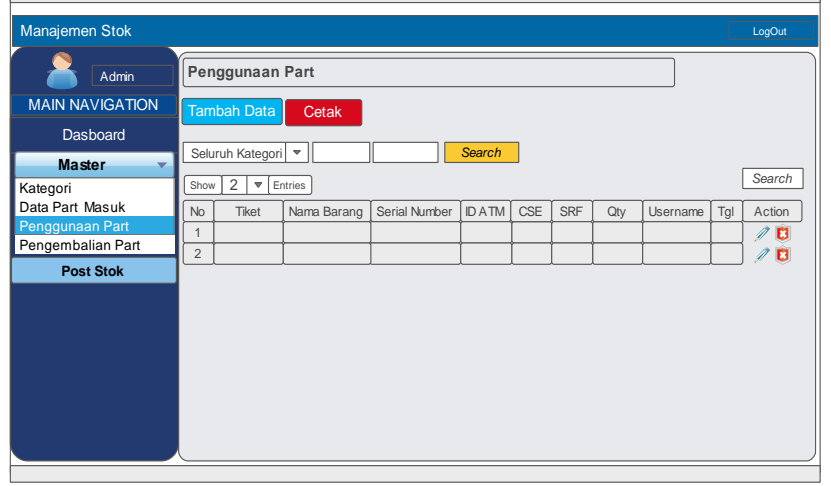

Gambar 14. Tampilan Antarmuka Data Penggunaan Part

\subsubsection{Data Pengembalian Part}

Menu data pengembalian part merupakan tampilan menu tentang semua data part bad yang digunakan pada ATM, yang selanjutnya dikembalikan oleh CSE dan diinput pada sistem sebagai barang Bad Rolable yang kemudian akan dikembalikan ke Logistik pusat untuk nantinya dapat di-repair kembali. Berikut merupakan hasil perancangan antarmuka untuk aktivitas pada data pengembalian part yang dapat disajikan melalui gambar 15 berikut, yaitu:

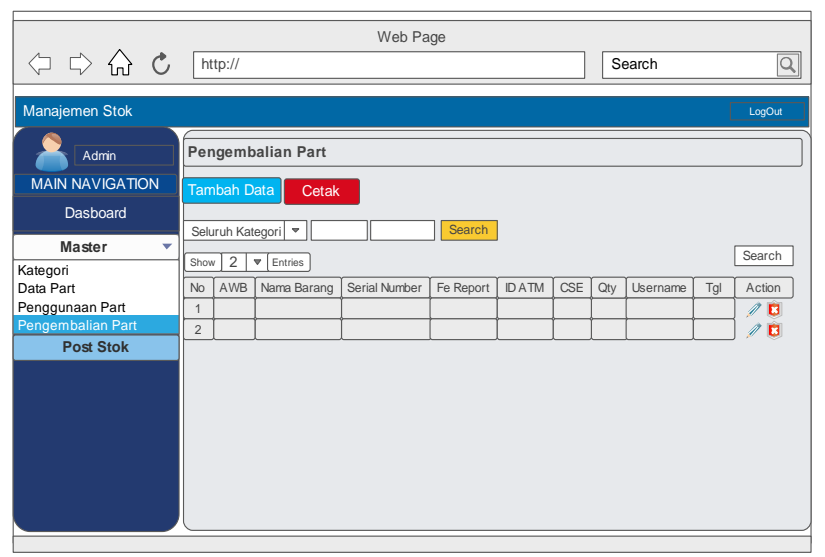

Gambar 15. Tampilan Antarmuka Data Pengembalian Part

\section{KESIMPULAN}

Berdasarkan hasil analisis dan perancangan arsitektur Model SIM Sparepart ATM yang dilakukan pada Logistik ASP , maka dapat disimpulkan beberapa hal sebagai berikut:

a. Hasil analisis dan perancangan arsitektur Prototipe Manajemen Sparepart ATM yang dilakukan telah memenuhi dan sesuai dengan kebutuhan manajemen pada Logistik ASP . Hal ini didasarkan pada hasil perancangan EA yang telah mengidentifikasi kebutuhan dalam memanajemen maupun pengelolaan sparepart yang telah dimodelkan ke dalam tiga baris cakupan Zachman Framework yang meliputi perancangan secara contextual, conceptual, dan logical di mana rancangan EA tersebut telah dapat mengakomodasi maupun menguraikan kebutuhan dalam mengontrol seluruh aktivitas pada data part.

b. Hasil pengujian kelayakan perancangan EA Prototipe Aplikasi Manajemen Sparepart ATM pada Logistik ASP dinyatakan "Layak" dengan hasil uji kelayakannya sebesar 76,18\% dan dapat menggambarkan situasi setiap area atau elemen-elemen EA yang dibutuhkan.

\section{UCAPAN TERIMA KASIH}

Penulis neghaturkan ucapan terima kasih kepada Universitas Amikom, Stikom Ambon, yang telah membantu saya dalan penulisan karya ilmiah ini.

\section{REFERENSI}

[1] Rahayu, S., Hadiana, A., 2016, "Perancangan Enterprise Architecture Berbasis Service menggunakan Zachman Framework: Studi Kasus PDAM Kota Sukabumi”, Jurnal Teknologi Rekayasa - JTERA, Vol. 1, No.1, Hal. 59 - 66, Desember 2016

[2] Schekkerman, J., 2005, Trends in Enterprise Architecture 2005: How are Organizations Progressing?, Edisi 1.0, Institue For Enterprise Architecture Developments, Netherlands

[3] Rijanto, E., Sabariah, M. K., Muttaqien, M. A., 9 Juni 2017 Perancangan Arsitektur Sistem Informasi Advertising Agency pada PT XYZ dengan Kerangka Kerja Zachman, https://ojs.unikom.ac.id/index.php/jtk3ti/article/view/316

[4] Nugraha, U., 2017, Analisis dan Perancangan Sistem Informasi Pendataan Warga dan Iuran menggunakan Kerangka Kerja Zachman, Seminar Nasional Teknologi Informasi dan Multimedia, STMIK AMIKOM Yogyakarta, ISSN: 2302 - 3805, Februari 2017

[5] Prananingrum, M. A. C. D., Sari, W. S., 2017, Pemodelan Enterprise Architecture Sistem Informasi Akademik SMA PL Don Bosko 
Semarang dengan Framework Zachman, Techno.COM, Vol. 16, No. 2, Hal. 208 - 219, Mei 2017

[6] Aswati, S., Firmansyah, A. U., Ramdhan, W., Suhendra, 2017, Analisis dan Perancangan Sistem Informasi Data Siswa pada Sekolah Menengah Kejuruan (SMK) PGRI 8 Medan dengan Zachman Framework, Jurnal SISFO, Vol. 6, No. 3, Hal. 309 - 318, Mei 2017

[7] Asefzadeh, S., Mamikhani, J., Navvabi, E., 2017, Determination of Gap in Accreditation Standards Establishment Process Using Zachman Framework at a Health-Educational Hospital, Biotech Health Sci, Vol. 4, No. 2, Agustus 2017

[8] Hengki, Suprawiro, S., 2017, Analisis dan Perancangan Sistem Informasi Inventory Sparepart Kapal Berbasis Web: Studi Kasus Asia Group Pangkalpinang, Jurnal SISFOKOM, Vol. 6, No.2, September 2017
[9] Pramudita, R., Safitri, N., 2016, Integrasi Zachman Framework dan TOGAF ADM (Architecture Development Method), Information System for Educators and Professionals, E-ISSN: 2548-3587, Vol. 1, No. 2, Hal. 157 - 166, Juni 2016

[10] Wibowo, A., Rijanto, E., Sabariah, M. K., 9 Juni 2017, Perancangan Enterprise Architecture untuk Menerapkan Innovation Management System di LPIK-ITB menggunakan Kerangka Kerja Zachman, https://ojs.unikom.ac.id/index.php/jtk3ti/article/download/311/277\&ve d=2ahUKEwjixpbi5MjbAhXCXSsKHf3a

[11] Lasimin, Kusrini, Lutfi, E. T., 2016, Enterprise Architecture Planning Manajemen Kampus di STIKES AL-IRSYAD AL-ISLAMMIYAH Cilacap, Jurnal PPKM III (2016), 219 - 228, ISSN: 2354-869X

[12] Utami, M., Kusrini, Arief, M. R., 2017, Arsitektur Aplikasi Mobile Commerce Untuk Micro Enterprise, Jurnal Pseudocode, Vol. 4, No. 2, September 201 